\title{
Blotting techniques for the study of DNA, RNA, and proteins
}

\author{
Peter C Hayes, C Roland Wolf, John D Hayes
}

Identifying and measuring specific proteins in complex biological mixtures, such as blood, have long been important goals in scientific and diagnostic practice. More recently the identification of abnormal genes in genomic DNA has become increasingly important in clinical research and genetic counselling. Blotting techniques are used to identify unique proteins or nucleic acid sequences. They have been developed to be highly specific and sensitive and have become important tools in both molecular biology and clinical research.

\section{General principle}

The blotting methods are fairly simple and usually consist of four separate steps: electrophoretic separation of protein or of nucleic acid fragments in the sample; transfer to and immobilisation on paper support; binding of analytical probe to the target molecule on paper; and visualisation of bound probe. Molecules in a sample are first separated by electrophoresis and then transferred on to an easily handled support medium, or membrane (table). This immobil-

Membrane supports and applications

\begin{tabular}{ll}
\hline Support medium & Macromolecules bound \\
\hline Nitrocellulose paper': & DNA, RNA, protein \\
Diazophenyl paper' & DNA, RNA, protein \\
Charge modified nylon sheets & Protein \\
Polyvinylidine difluoride membrane"* & Protein \\
Glass fibre': & \\
Aminopropyl & Protein \\
Quaternary ammonium & Protein \\
Phenylenediisothiocyanate & Protein
\end{tabular}

ises the protein or DNA fragments, provides a faithful replica of the original separation, and facilitates subsequent biochemical analysis. After being transferred to the support medium the immobilised protein or nucleic acid fragment is localised by the use of probes, such as antibodies or DNA, that specifically bind to the molecule of interest. Finally, the position of the probe that is bound to the immobilised target molecule is visualised, usually by autoradiography.

Three main blotting techniques have been developed and are commonly called Southern, northern, and western blotting. Southern blotting, named after its originator,' allows DNA fragments to be identified with probes of DNA, which hybridise by hydrogen bonding to complementary fragments of chromosomal DNA. Northern blotting " allows individual molecules of messenger RNA (mRNA) to be identified and measured after hybridisation to their corresponding DNA sequences (the sequences of DNA from which the mRNA was transcribed). By contrast, western blotting allows particular proteins to be identified with specific antibodies used as analytical probes. ${ }^{12}$

\section{Methods}

SOUTHERN AND NORTHERN BLOTTING

A prerequisite for both Southern and northern blotting is the availability of cloned DNA or synthetic DNA sequences that can be used as probes for the gene of interest. The synthesis of such probes is described later in this series. ${ }^{1314}$ Southern blotting is a DNADNA hybridisation technique that is often used to identify, for example, the location of a single gene on chromosomal DNA (fig l).

Before Southern blot analysis can be carried out

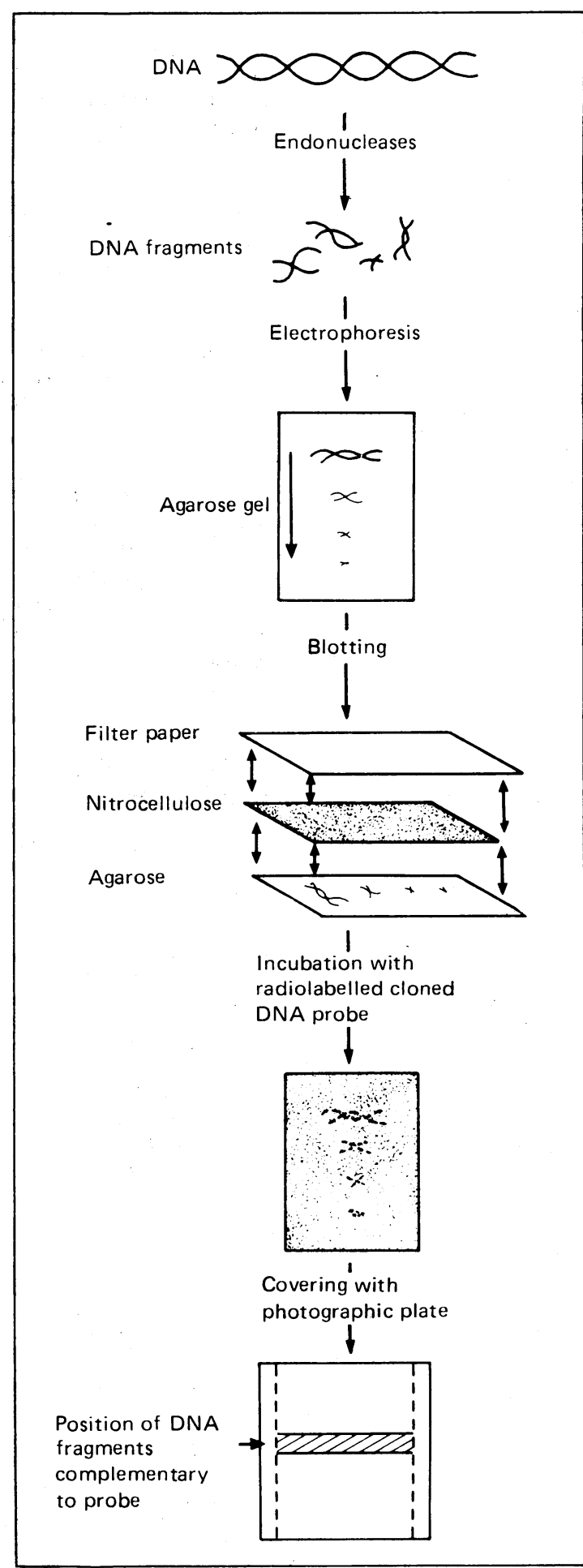

FIG 1-Southern blotting
J D Hayes, Royal Infirmary, Edinburgh.

BrMed f 1989;299:965-8

1989

14 OCTOBER 1989 
fragments of DNA must be produced from chromosomes by enzymic digestion with restriction endonucleases. These enzymes are obtained from microorganisms and digest double stranded DNA at specific cleavage sites determined by the nucleic acid sequence. As restriction endonucleases cleave DNA at only these cleavage sites each enzyme produces a characteristic number of fragments from a single specific length of DNA. Allelic variants of a particular gene can be detected if the differences in the nucleic acid sequence include the cleavage sites because digestion by the appropriate restriction enzyme will yield different fragments from allelic genes (fig 2). Hence mutations may result in either the loss of cleavage sites or the introduction of new, additional cleavage sites. Such differences in the fragments produced from one gene are referred to as restriction fragment length polymorphisms (RFLPs). ${ }^{13}$

After enzymic digestion of chromosomal DNA the resulting DNA fragments are subjected to electrophoresis in agarose, which separates the fragments according to size, the smaller DNA fragments migrating furthest in the electric field. ${ }^{15}$ The electrophoresis gel is then covered with a sheet of nitrocellulose, on to which the DNA is absorbed. Before hybridisation mild denaturation in alkaline solution ensures that the blotted DNA is single stranded. The nitrocellulose sheet is then incubated with the gene probe, which is usually cloned DNA. ${ }^{1+}$ The gene probe will have been radiolabelled, and it hybridises by hydrogen bonding to single stranded chromosomal DNA fragments that contain complementary nucleic acid sequences. The nitrocellulose sheet is then dried and covered by a photographic or $x$ ray film to allow localisation of the gene under examination (fig 3).

Northern blotting entails essentially the same process described above except that complementary DNA is used to probe RNA. Messenger RNA is first separated according to size by electrophoresis and then transferred to paper before gene probes are used to locate the message of interest. With this method the transcripts of specific genes can be studied and measured.
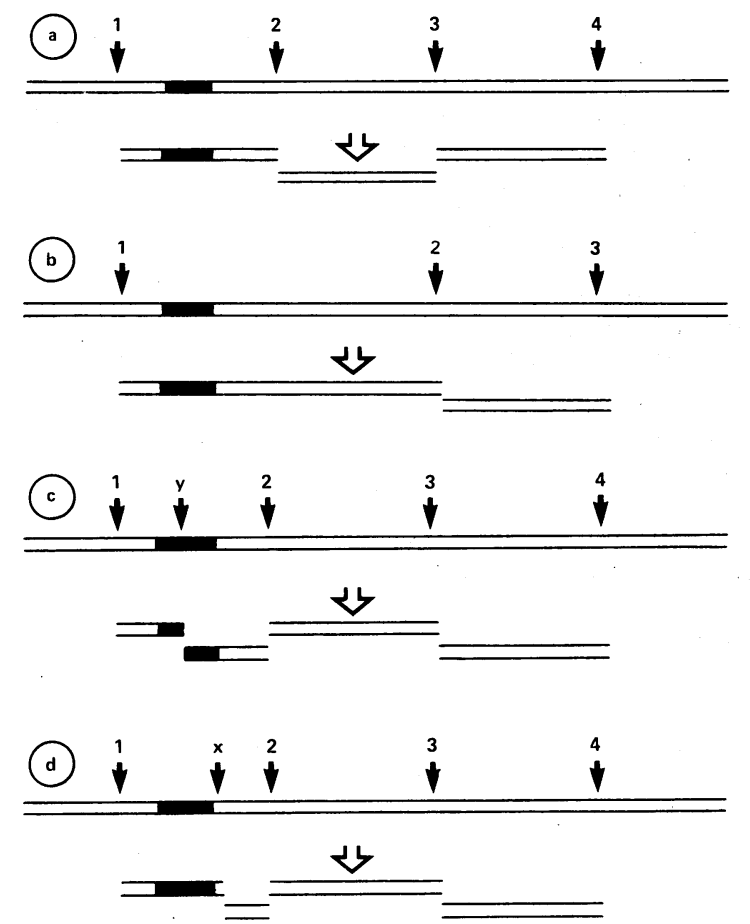

FIG 2-Sites of enzyme digestion by endonucleases: (a) cleavage of DNA at positions $1,2,3$, and $4 ;(b)$ cleavage with loss of restriction site $2 ;(c)$ cleavage with additional restriction site $y ;(d)$ cleavage with additional restriction site $x$ arising in region corresponding to gene probe (blackened region)

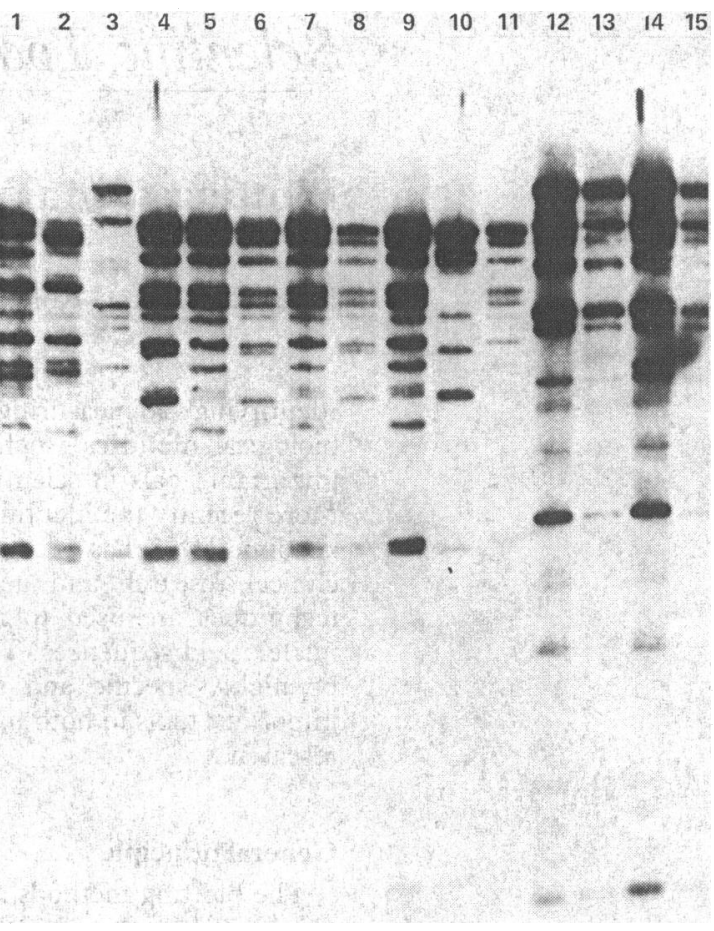

FIG 3-Example of Southern blotting. Fifteen rows of different DNA fragments separated by electrophoresis and identified with cytochrome P-450 complementary DNA probe

\section{WESTERN BLOTTING}

The specific antibodies to the protein under examination are needed for western blotting. The sources of these antibodies may be serum samples (for example, from patients with known infections), purified polyclonal antibody preparations, or monoclonal antibodies. ${ }^{16}$

As a consequence of the interaction of antibody and antigen the target protein (the antigen) when immobilised on a paper support can be identified with antibodies. The mixture containing the protein under investigation is first resolved into its components by electrophoresis in polyacrylamide gels, ${ }^{15}$ and the proteins are then transferred to nitrocellulose paper (fig 4). The primary antibody binds to its target protein and is immobilised on the blotting support. The antigen-antibody complex can then be identified with antibodies to the primary antibodies, which are labelled with radioactive iodine (fig 5), and can then be visualised by autoradiography. The labelling antibody can be removed and the protein studied further.

\section{Applications \\ SOUTHERN BLOTTING}

Less than 10 years ago DNA polymorphisms were first identified in the $\beta$ globin gene for haemoglobin. ${ }^{17}$ Since then DNA probes have been used increasingly in medical research, in particular for identifying genes associated with genetically transmitted diseases so that restriction fragment length polymorphisms have now been found in Huntington's chorea, ${ }^{18}$ familial growth hormone deficiency, ${ }^{14}$ sickle cell anaemia, ${ }^{20}$ adult polycystic kidney disease, ${ }^{21}$ and cystic fibrosis." The recent application of Southern blotting to cystic fibrosis has incriminated a DNA sequence very close to an allele'named $\mathrm{pJ} 3.11$ which provides a crucial clue in the search for a "cystic fibrosis" gene..$^{23}$ Once the structure of the gene is known it should not be long before the putative protein thought to be causing the disease is identified. ${ }^{2+}$ Investigation of diseases with less obvious genetic transmission, such as ischaemic heart disease, have used DNA probes with provocative results. ${ }^{25}$ With gene probes for apolipoprotein B certain alleles 
were identified in many patients with ischaemic heart disease. Interestingly, none of these alleles was associated with variations in cholesterol or apolipoprotein $B$ concentrations, suggesting that genetic variation at the locus for apolipoprotein may be an independent, though unknown, risk factor for ischaemic heart disease.

Such investigations have therefore improved our understanding of many diseases and have also greatly improved our ability to diagnose some of them before symptoms develop. Also, antenatal diagnosis has great potential in genetic counselling and is already being applied to such conditions as Duchenne type and Becker's muscular dystrophy. ${ }^{26}$

Southern blotting has also been applied to investigation of malignant disease. For example, hepatocellular carcinoma, one of the commonest cancers in the world,

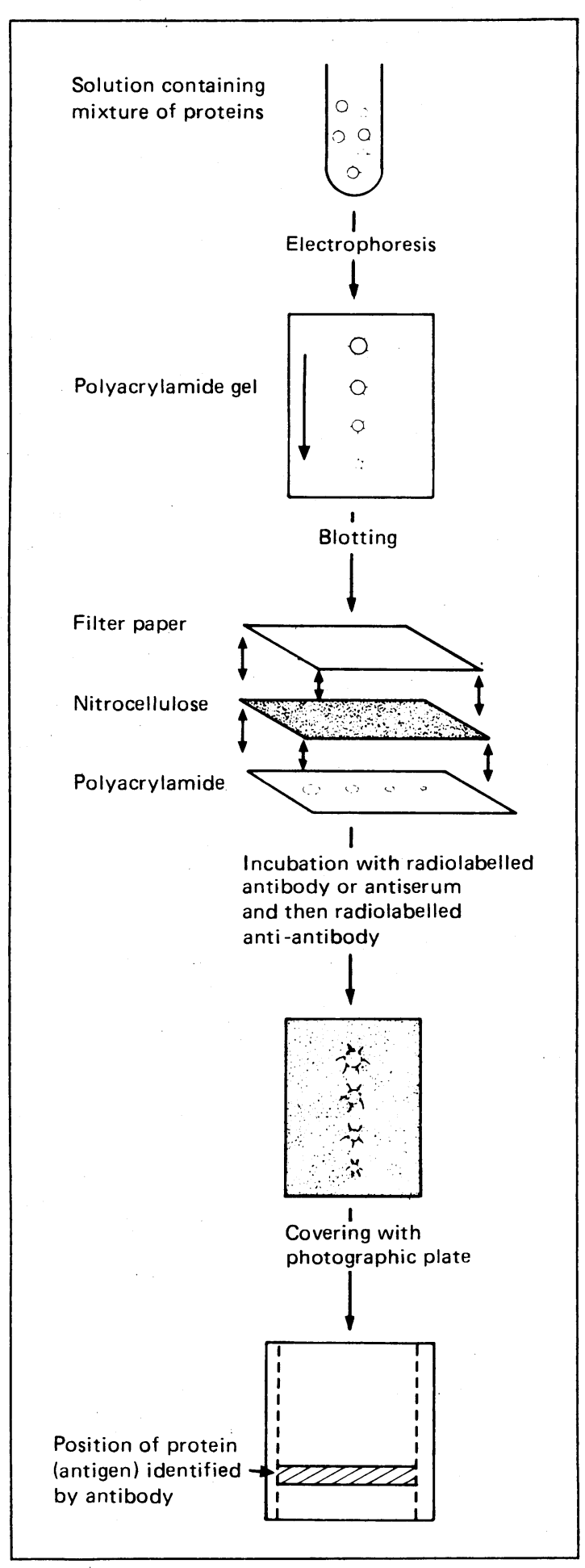

FIG 4-Western blotting
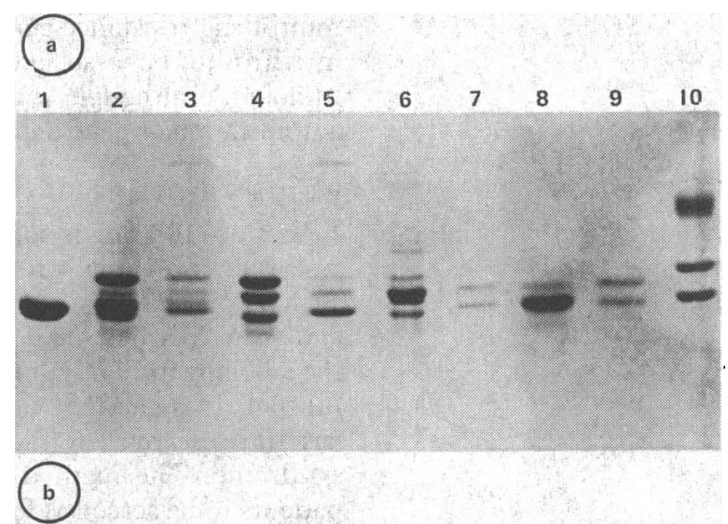

FIG 5-Example of western blotting: (a) 10 samples separated by electrophoresis and different proteins identified with a general protein stain; (b) the specific polypeptide Yk picked out by antibody to $Y k$

has been recognised for years to be associated in many geographic regions with hepatitis B virus infection. Blotting techniques have shown that DNA from the hepatitis B virus is incorporated into the genome of both hepatocellular carcinoma cell lines and tumours. ${ }^{27}$ Such information increases our understanding of carcinogenesis and should lead to improvements in treatment and prevention.

\section{Problems}

The usefulness of these tests relies on gene linkage analysis when the exact site of the abnormal gene is unknown, as often happens. The probes used usually detect nucleic acid sequences close to, rather than within the affected gene. As "swapping" recombination occurs between genes of paired chromosomes, in about $5 \%$ of samples the probe marker will no longer be physically associated with the abnormal gene, resulting in a probability of detecting carriage of the gene of only $95 \% .^{28}$ The accuracy of this method obviously varies, depending on how close the nucleic acid sequence that is being identified is to the gene under study: the larger the distance the higher the probability of error. Such a limitation does not apply to probes for genes already known to be responsible for the disease.

A further potential problem of applying these techniques to inherited diseases is that of heterogeneous genes for clinically similar disorders. Thus information relating to a patient's pedigree is essential for accurate analysis of certain diseases, such as autosomal dominant manic depressive disease, in which genetic heterogeneity is known to exist. ${ }^{28}$

\section{NORTHERN BLOTTING}

Northern blotting, which uses DNA probes that hybridise with complementary RNA sequences, is an ideal tool to study the products of gene transcription. For example, overexpression of certain proteins in neoplastic cells can be examined to determine whether the increase is due to gene amplification (an increase in the number of genes), is regulated at a transcriptional level due to gene derepression (where one gene gives rise to increased mRNA), or is due to post-transcriptional mechanisms such as reduced cellular excretion. Gene amplification has been shown to be responsible for acquired drug resistance in tumour cells in small cell carcinoma, where methotrexate resistance is conferred by amplification of the gene for dihydrofolate reductase.${ }^{29}$ Multiple drug resistance, conferred by the 
multi-drug resistance gene (MDR-1), has been shown in vitro to be associated with increased RNA in tumours, ", although whether this is due to gene amplification or gene derepression is unknown.

\section{WESTERN BLOTTING}

Western blotting is currently widely used in clinical research. Individual proteins from a protein mixture such as plasma or other body fluids can be identified and then "rescued" and further studied by removing the labelling antibody, making the technique a powerful tool. It is gaining widespread application particularly for research into the acquired immunodeficiency syndrome. The method allows serum samples from patients to be screened for antibodies against a variety of viral antigens. It uses the antibodies in the serum as "probes" to show the presence of known viral antigens that have been run on an electrophoretic strip. By the use of standard - that is, positive-antisera, antigens from different sources can be studied and cross reactivity identified. In this way closely related HIV-I and HIV-II can be detected and differentiated." The specificity of western blotting is also used to check positive results of enzyme linked immunosorbent assay (ELISA) tests for the AIDS virus, thereby reducing the risks of finding false positive results, ${ }^{32}$ the technique has also been applied to other viral diseases, including hepatitis B. It can be used, for example, to test for antibody production in the serum of patients vaccinated with synthetic vaccines. ${ }^{33}$

Western blotting has also proved invaluable in protein chemistry applied to such areas as enzymology and oncology - for example, to find different isoenzymes and their pattern of distribution in diseased and healthy tissue. Similarly, the identification and localisation of tumour markers within neoplastic material can easily be studied with the appropriate antisera.

\section{Future developments}

The application of blotting techniques will undoubtedly increase in the next decade. It is likely that rather than being employed in isolation they will complement other areas of technological advance outlined in this series. An example of this is the polymerase chain reaction, in which special heat resistant DNA polymerase enzymes are used to duplicate very small segments of DNA that would otherwise go undetected. Once amplified such DNA segments are identified by Southern blotting. This technique has been used to identify infection with HIV many months before antibodies can be detected in the patient's serum. ${ }^{3+}$

Blotting techniques, which allow detection of genomic material or proteins fairly simply and cheaply with high specificity, are widely used in medical research. Nevertheless, the results depend on the purity of the materials used and the technical skill of those using them.

We thank Dr J Miles for helpful criticism, Drs N Hastie and $\mathrm{R}$ Meehan for providing the examples of Southern blotting, and Mrs J Johnstone for typing the manuscript.

1 Southern EM. Detection of specific sequences among DNA fragments separated by gel electrophoresis. F Mol Biol 1975;98:503-17.

2 Thomas P. Hybridization of denatured RNA and small DNA fragments transferred to nitrocellulose. Proc Natl Acad Sci USA 1980;77:5201-5.

3 Towbin H, Stachelin T, Gordon J. Electrophoretic transfer of proteins from polyacrylamide gels to nitrocellulose sheets: procedure and some applications. Proc Natl Acad Sci USA 1979;76:4350-4.

4 Alwine JC, Kemp DJ, Parker BA, et al. Detection of specific RNAs or specific fragments of DNA by fractionation in gels and transfer to diazobenzyloxymethyl paper. Methods Enzymol 1979:68:220-42.

5 Renart J, Reiser J, Stark GR. Transfer of proteins from gels of diazobenzyloxymethy paper and detection with antisera: a method for studying anibody specificity and antigen structure. Proc Natl Acad Sci USA 1979;76:3166-20.
Glossary

Genomic DNA - DNA derived from chromosomes

Probe

- an agent that will accurately identify a specific nucleic acid or amino acid sequence

Autoradiography - the process whereby the radioactivity of isotopes is detected by photographic film applied on to the isotope labelled probe

Hybridisation

- the process of bonding of a sequence of nucleic acid bases to complementary bases

Specificity

- the ability to identify a substance accurately, allowing few false positives

Sensitivity

- the ability to identify all tested substances, allowing few false negatives

6 Bittner M, Kupferer P, Morris CF. Electrophoretic transfer of proteins and nucleic, acids from slab gels to diazobenzyloxymethyl cellulose or nitrocellunucleic acids from slab gels to diazobenzyly
lose sheets. Anal Biochem 1980;102:+59-71.

7 Gershoni JM. Palade GE. Electrophoretic transfer of proteins from sodium dodecyl sulphate-polvacrylamide gels to a positively charged membrane dodecy sulphate-polvacrylamide gels

8 Pluskal MG, Przekop MB, Kavonian MR. Immobilon PVDF transfer membrane: a new membrane substrate for western blotting of proteins. Bio Techniques 1986;4:272-83

9 Matsudaira P. Sequence from picomole quantities of proteins electroblotted onto poly vinylidene difluoride membranes. F Biol Chem 1987;262: 10035-8.

10 Aebersold RH, Teplow DB, Hood LE, Kent SBH. Electroblotting onto activated glass: high efficiency preparation of proteins from analytical SDSpolyacrylamide gels for direct sequence analysis. I Biol Chem 1986;261 +22938 .

11 Thomas PS. Hybridization of denatured RNA transferred on dotted nitrocellulose paper. Methods Enzymol 1983;100:255-66.

12 Towbin $\mathrm{H}$, Gordon $\mathrm{J}$. Immunoblotting and dot immunobinding: current status and outlook. F Immunol Methods 1984;72:313-40.

13 Botstein D, White RL, Skolnick M, Davis RW. Construction of a genetic linkage map in man using restriction fragment length polymorphisms. Am $\mathcal{J}$ Hum (i'ne't 1980;32:31+-31.

It Miles JS, Wolf CR. DNA cloning. $B r$ Med $J$ (in press). 15 Haves JD, Stockman PK. Electrophoresis of proteins and nucleic acids. II.
Techniques and applications. Br Med f 1989;299:907-10.

16 Roulston JE. Monoclonal antibodies as a clinical tool. Br Med J (in press).

17 Kan YW, Do\%y AM. Polymorphism of DNA sequence adjacent to human $\beta$ globulin structured gene relationship to sickle mutation. Proc Natl Acad Sci CSA 1973;75:5631-5.

18 Gusella JF, W'exler NS, Conneally PM, et al: A polymorphic DNA marker genetically linked to Huntington's chorea. Nature 1983;306:234-8.

19 Phillips JA, Parks JS, Hjelle BL, Herd JE, Plotnick P. Genetic analysis of familial isolated growth hormone deficiency type 1. F Clin Invest 1982;70: 48995.

20 Orkin S. Prenatal diagnosis of hemoglohin disorders by DNA analysis. Blood 1984;63:249-53.

21 Reeders ST, Browning MH, Davies KE, et al. A highly polymorphic DNA marker linked to adult polycystic kidney disease in carcinoma. Nature $1985 ; 317: 5+2-4$

22 White $\mathbf{R}$, Woodward S, Leppert M, et al. A closely linked genetic marker for crstic fibrosis. Nature 1985;318:382-4.

23 Williamsons R. The cysstic fibrosis locus: a progress report. Disease Murkers 1987;5:59-63.

24 Robinson.AC. DNA sequencing. Br.Med $\mathcal{J}$ (in press).

25 Hegele RB, Huong L-S, Herbert PM, ct al. A polipoprotein B-gene DNA polvmorphisms associated with myocardial infarction. $N$ lingl f $\mathrm{Med}$ 1986;315:1509-15

26 Cole CG, Walker A, Coyne A, et al. Prenatal testing for Duchenne and Becker muscular d'strophy. Langet 1988;i:263-5.

27 Zuckerman AJ, Harrison TJ. Hepatitis B virus chronic liver disease and hepatocellular carcinoma. Postyrad Med f 1987;63(suppl 2):13-20.

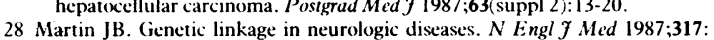
1018-20.

29 Curt GA, Carney DN, Cowan KH, et al. Unstable methotrexate resistance in human small-cell carcinoma associated with double minute chromosomes. human small-cell carcinoma associac

30 Fojo AT, Veda K, Slaman DJ, et al. Expression of multidrug-resistance gene in human tumors. Proc Natl Acad Sci USA 1987;84:265-9.

31 Werner A. Staszewski S, Helm E-B, et al. HIV-2 (West Germany, 1984). L.ancet 1987; i:868-9.

$32 \mathrm{Nzilambi}$, De Cock KM, Forthal DN, et al. The prevalence of infection with human immunodeficiency virus over a 10 -year period in rural Zaire. $N \mathrm{Engl}$ f Med 1988;318:276-9.

33 Petre J, Van Wijnendaele F, De Neys B, et al. Development of a hepatitis B vaccine from transformed yeast cells. Postgrad Med J 1987;63(suppl 2): 7382.

34 Anonymous. New technique reveals extent of viral variations. New Scientist 1988 June 23:37. 